\title{
PERSPEKTIF KRIMINOLOGI DAN VIKTIMOLOGI TERHADAP KASUS TINDAK PIDANA PEDOFILIA MENURUT PERATURAN PEMERINTAH PENGGANTI UNDANG-UNDANG NOMOR 1 TAHUN 2016 TENTANG PERLINDUNGAN ANAK
}

\author{
Reza Wahyu Pratama ${ }^{1}$ \\ Riky Pribadi $^{2}$
}

\begin{abstract}
ABSTRAK
Tindak pidana pedofilia seringkali terjadi di Indonesia, hal ini dapat dilihat dari berbagai media massa. Namun demikian kasus tersebut hanya sebagian yang dapat terungkap dan diselesaikan melalui jalur hukum. Pedofilia adalah perbuatan yang dilakukan oleh orang dewasa dalam hal seksual, karena adanya kepuasan ketika melakukan hubungan seksual tersebut dengan anakanak. Korban dari dari tindak pidana pedofilia adalah anak, dimana anak yang merupakan titipan dari Tuhan Yang Maha Esa yang harus dijaga dan dilindungi. Berdasarkan Peraturan Pemerintah Pengganti Undang-Undang Nomor 1 Tahun 2016 Tentang Perlindungan Anak, Dihubungkan dengan Kriminologi dan Viktimologi. Adapun tujuan penelitian ini untuk mengetahui dan memahami bagaimana penegakan hukum terhadap pelaku tindak pidana pedofilia dan untuk mengetahui dan memahami faktor-faktor apa saja yang menyebabkan tindak pidana pedofilia, serta untuk mengetahui dan memahami upaya perlindungan terhadap anak yang menjadi korban tidak pidana pedofilia. Dalam hal penulisan skripsi ini agar dapat mempermudah dalam proses penelitian, penulis menggunakan beberapa teori seperti Teori Negara Hukum, Teori Penegakan Hukum, Teori Perlindungan Hukum, dan Teori Kriminologi.

Metode yang digunakan dalam penelitian skripsi ini adalah metode pendekatan yuridis empiris yaitu pendekatan atau penelitian hukum yang menggunakan sumber-sumber data primer, sekunder dan tersier seperti peraturan perundang-undangan, sejarah hukum, teori-teori hukum dan pendapat-pendapat sarjana hukum yang berhubungan.

Berdasarkan hasil penelitian yang dilakukan oleh penulis bahwa Penegakan hukum pidana terhadap pelaku tindak pidana pedofilia belum efektif, karena belum mampu memberikan efek jera terhadap pelaku pedofilia dan masih terdapat beberapa kendala dalam penegakan hukumnya, Kebijakan pemidanaan bagi pelaku pedofilia dalam hukum positif Indonesia pada dasarnya memiliki tujuan pemidanaan yakni untuk memperbaiki pribadi dan penjahat itu sendiri, untuk membuat orang menjadi jera, untuk membuat penjahat-penjahat tertentu menjadi tidak mampu untuk melakukan kejahatan lain. Faktor-faktor yang menyebabkan pedofilia adalah sebagai berikut : Hubungan keluarga yang tidak harmonis, riwayat sebagai korban kekerasan seksual saat masih berusia kanak-kanak, gangguan kepribadian antisosial,
\end{abstract}

\footnotetext{
${ }^{1}$ Mahasiswa Fakultas Hukum Universitas Majalengka

${ }^{2}$ Dosen Fakultas Hukum Universitas Majalengka. Email : rikypribadi87@unma.ac.id
} 
kecanduan obat-obatan, depresi, faktor genetic, faktor lingkungan, ketidak seimbangan hormon dan IQ yang rendah. Upaya yang dilakukan dalam perlindungan korban pedofilia adalah Koseling, Pelayanan atau Bantuan Medis dan Bantuan Hukum serta Pencegahan tehadap tindak pidana pedofilia.

Kata Kunci : Penegakan Hukum, Pedofilia. 
PRESUMPTION of LAW

Fakultas Hukum Universitas Majalengka

Volume 3 Nomor 2 Oktober 2021

\section{A. Latar Belakang Masalah}

Anak sebagai makhluk Tuhan Yang Maha Esa dan sebagai makhluk sosial sejak dalam kandungan, mempunyai hak untuk hidup dan merdeka serta mendapat perlindungan. oleh karena anak baik secara rohani maupun jasmani belum mempunyai kemampuan untuk berdiri sendiri, maka menjadi kewajiban bagi orang tua, keluarga, masyarakat, bangsa dan negara untuk melindungi, menjamin, memelihara dan mengamankan kepentingan anak tersebut. Setiap anak berhak atas kelangsungan hidup, tumbuh dan berkembang serta berhak atas perlindungan dari kekerasan dan diskriminasi.

Salah satu tindak pidana yang menjadi fenomena akhir-akhir ini kekerasan seksual terutama terjadi pada anak salah satunya yaitu pedofilia, Pedofilia adalah orang yang mengidap gangguan seksual berupa nafsu terhadap anak-anak atau remaja yang berusia dibawah umur. pedofili akan berdampak negatif bagi anak. Bukan merusak masa depan secara fisik saja, tetapi juga akan merusak mental dan kejiwaan anak, seperti gangguan depresi berat dapat terbawa kelak hingga dewasa. apalagi kebanyakan penderita pedofilia disebabkan karena dirinya pernah menjadi korban pelecehan seksual serupa pada masa anak-anak.

Dilihat dari ragam bentuk karakteristik perbuatan kaum pedofil terhadap anak seperti itu, bisa dikatakan anak-anak dieksploitasi. Sehingga anak adalah korban yang mestinya dilindungi dan memperoleh pelayanan khusus, dan seharusnya ada norma dan hukum yang tegas untuk melindungi anak-anak, sehingga secara yuridis, pihak yang bertanggung jawab adalah eksploitatornya. Tindak pidana pedofilia sangat merugikan korban dan masyarakat luas. Penderitaan korban akibat perbuatan kaum pedofilia tidak berupa penderitaan fisik saja, tetapi juga menderita secara psikologis atau mental. Oleh karena itu korban membutuhkan perhatian dan perlindungan hukum.

Kasus pedofilia sering terjadi di Indonesia menunjukan bahwa pelaku yang melakukan kejahatan pedofilia ini bisa terjadi karena beberapa hal, yaitu pernah mengalami pelecehan seksual pada masa anak-anak dahulu. Maka dari itu perlulah kita mengingat bahwa orang-orang yang menjadi pelaku sebenarnya merupakan korban dari kekerasan seksual juga. oleh itu melihat semakin banyak anak yang menjadi korban kasus pedofilia maka pemerintah perlu membentuk peraturan yang mana untuk melindungi anak yang menjadi korban dan menekan agar diharapkan tidak lagi terjadi kasus demikian dikemudian hari.

Perlindungan anak adalah segala kegiatan untuk menjamin dan melindungi anak dan hak-haknya agar dapat hidup, tumbuh dan berkembang, dan berpartisipasi secara optimal sesuai dengan harkat dan martabat kemanusiaan. Jadi yang harus dilindungi adalah semua anak. Adapun tujuan dari perlindungan adalah untuk menjamin terpenuhnya hak-hak anak.

Setiap anak berhak untuk mendapatkan perlindungan hukum dari segala bentuk kekerasan fisik atau mental, penelantaran, perlakuan buruk, dan pelecehan seksual selama dalam pengasuhan orang tua atau walinya, atau pihak lain manapun yang bertanggung jawab atas pengasuhan anak tersebut. Dalam pasal pasal 20 Undang-Undang Nomor 35 Tahun 2014 tentang perlindungan 
PRESUMPTION of LAW

Fakultas Hukum Universitas Majalengka

Volume 3 Nomor 2 Oktober 2021

anak akan lebih luas lagi siapa saja yang bertanggung jawab atas penyelengaraan perlindungan anak, yaitu negara, pemerintah daerah, masyarakat, keluarga, dan orang tua atau wali berkewajiban.

Namun kenyataannya tidaklah demikian, anak sebagai korban perlakukan kekerasan sering terabaikan oleh lembaga-lembaga kompeten dalam sistem peradilan pidana, yang seharusnya memberikan perhatian dan perlindungan yang cukup berdasarkan hukum. Hal tersebut tidak seharusnya terjadi, sebab sebagaimanapun korban tetap mempunyai hak untuk diperlakukan adil, dan dilindungi hak-haknya.

Perubahan paradikma dalam kriminologi memberikan pemahaman dalam viktimologi, timbulnya kesadaran bahwa masalah kejahatan atau kausa kejahatan tidak cukup dipelajari melalui perbuatannya atau pelakunya. Oleh karena itu disamping pelanggaran Undang-Undang, juga perubahan Undangundang pidana dan penerepannya menjadi fokus persoalan untuk mengkaji bekerjanya kepentingan yang memengaruhi para pihak yang terlibat dalam proses viktimisasi terhadap korban, yaitu aparat penegak hukum, termasuk bagaimanakah penegakan hukum berinterpretasi dan bertindak dalam interaksinya dengan korban atau pelaku.

Hukum di Indonesia yang menjerat pelaku pedofilia tidaklah serius, sehingga hukuman bagi kaum pedofilia tidaklah setimpal dengan apa yang diperbuat dan resiko rusaknya masa depan para korban. Selain itu perlindungan bagi masyarakat bagi korban pedofil juga sangat kurang. Undang-Undang Nomor 23 Tahun 2002 tentang Perlindungan Anak telah diubah dengan Undang-Undang Nomor 35 Tahun 2014 serta Peraturan Pemerintah Pengganti Undang-Undang (Perppu) Nomor 1 Tahun 2016 tentang perlindungan anak telah mengatur sanksi pidana bagi pelaku kekerasan seksual terhadap anak, namun penjatuhan pidana tersebut belum memberikan efek jera dan belum mampu mencegah secara komprehensif terjadinya kekerasan seksual terhadap anak.

Mengingat Peraturan Pemerintah Pengganti Undang-Undang ini juga sudah cukup lama penulis berharap agar pemerintah secepatnya mengeluarkan Undang-Undang yang baru tentang perlindungan anak ini, karena perkembangan kasus kekerasan seksual terhap anak yang saat ini semakin meningkat dan meresahkan para orang tua ataupun keluarga para korban. Apabila terus dibiarkan akan memberikan dampak buruk terhadap anak yang menjadi korban tindak pidana pedofilia, mengingat anak merupakan tunas, potensi, dan generasi muda penerus cita-cita perjuangan bangsa. Anak memiliki peran strategis dalam kelangsungan eksistensi bangsa serta negara pada masa depan dan seharusnya kita selaku orang tua, keluarga, maupun negara wajib melindungi hak-hak terhadap anak.

Berdasarkan apa yang telah diuraikan tersebut diatas, maka penulis tertarik untuk melakukan penelitian yang disusun dalam bentuk Skripsi dengan judul : "PERSPEKTIF KRIMINOLOGI DAN VIKTIMOLOGI TERHADAP KASUS TINDAK PIDANA PEDOFILIA MENURUT PERATURAN PEMERINTAH PENGGANTI UNDANG-UNDANG NOMOR 1 TAHUN 2016 TENTANG PERLINDUNGAN ANAK" 
PRESUMPTION of LAW

Fakultas Hukum Universitas Majalengka

Volume 3 Nomor 2 Oktober 2021

\section{B. Rumusan Masalah}

Sesuai dengan latar belakang yang telah diuraikan diatas, maka identifikasi masalah penelitian ini ditetapkan sebagai berikut :

1. Bagaimana penegakan hukum terhadap pelaku tindak pidana pedofilia ditinjau kriminologi dan viktimologi ?

2. Faktor-faktor apa saja yang menyebabkan terjadinya tindak pidana pedofilia ?

3. Bagaimana upaya perlindungan hukum terhadap korban tindak pidana pedofilia?

\section{Tujuan Penelitian}

Adapun tujuan dalam hal penelitian ini yaitu untuk menambah wawasan pengetahuan dan pemahaman penulis akan arti pentingnya ilmu hukum dalam teori dan praktik menganalisis masalah hukum. Dan berdasarkan identifikasi masalah di atas, maka tujuan penelitian ini ditetapkan sebagai berikut :

1. Untuk mengkaji dan mengetahui penegakan hukum terhadap pelaku tindak pidana pedofilia ditinjau kriminologi dan viktimologi;

2. Untuk mengkaji dan mengetahui Faktor-faktor yang menyebabkan terjadinya tindak pidana pedofilia;

3. Untuk mengkaji dan mengetahui upaya perlindungan hukum terhadap korban tindak pidana pedofilia.

\section{Kerangka Pemikiran}

Indonesia adalah Negara Hukum seperti yang disebutkan dalam Pasal 1 Ayat (3) Undang-Undang Dasar Tahun 1945 yang berbunyi : "Negara Indonesia adalah Negara Hukum". Artinya segala tingkah laku warga negaranya harus sesuai dengan hukum yang berlaku atau hukum positif atau aturan-aturan lainnya seperti tidak bertentangan dengan undang-undang, norma-norma, kaidah-kaidah, asas-asas dan lain-lain.

Hal ini berlaku umum tanpa terkecuali, diantaranya seperti yang dilakukan oleh anggota Tentara Nasional Indonesia. Sebagaimana ditegaskan dalam Pasal 27 ayat (1) Undang-Undang Dasar Tahun 1945 menyatakan : "Setiap warga negara bersamaan kedudukannya di dalam hukum dan pemerintahan dan wajib menjunjung hukum dan pemerintahan itu dengan tidak ada kecualinya".

Agar dapat mempermudah dalam proses penelitian, penulis mencoba menggunakan beberapa teori seperti Teori Negara Hukum, Teori Keadilan, Teori Kedisiplinan, dan Teori Hukum Pembangunan.

1. Teori Negara Hukum

Teori merupakan pengetahuan ilmiah yang mencakup penjelasan mengenai suatu faktor dari sebuah disiplin ilmiah. Dalam dunia ilmu, teori menempati kedudukan penting, karena teori memberikan sarana untuk dapat merangkum serta memahami masalah yang dibicarakan secara lebih baik. 
PRESUMPTION of LAW

Fakultas Hukum Universitas Majalengka

Volume 3 Nomor 2 Oktober 2021

Hal-hal yang semula tampak tersebar dan berdiri sendiri dapat disatukan dan ditunjukkan kaitannya satu sama lain secara lebih bermakna. ${ }^{3}$

Indonesia adalah negara yang berdasarkan atas hukum menurut Pasal 1 ayat (3) Undang-Undang Dasar Negara Republik Indonesia 1945. Pasal ini menghendaki bahwa penyelenggaraan pemerintahan didasarkan atas prinsipprinsip hukum untuk membatasi kekuasaan pemerintah dan ini artinya kekuasaan negara melalui aparatnya dibatasi oleh hukum (rechtsstaat), bukan didasarkan atas kekuasaan (machtsstaat). ${ }^{4}$

Konsep negara hukum bersandar pada keyakinan bahwa kekuasaan negara harus dijalankan atas dasar hukum yang adil dan baik. Hubungan antara yang diperintah (governed) dan memerintah (governor) dijalankan berdasarkan suatu norma objektif, bukan pada suatu kekuasaan absolut semata-mata. Norma objektif tersebut harus memenuhi syarat formal dan dapat dipertahankan oleh ide hukum.

Negara hukum mensyaratkan bahwa setiap tindakan dari negara haruslah bertujuan untuk menegakkan kepastian hukum, dilakukan secara setara, menjadi unsur yang mengesahkan demokrasi, dan memenuhi tuntutan akal budi. Alat-alat negara mempergunakan kekuasaannya hanya sejauh berdasarkan hukum yang berlaku dan dengan cara yang ditentukan dalam hukum itu. Dalam negara hukum, tujuan suatu perkara adalah agar dijatuhi putusan sesuai dengan kebenaran. Tujuan suatu perkara adalah untuk memastikan kebenaran, maka semua pihak berhak atas pembelaan atau bantuan hukum. ${ }^{5}$

2. Teori Keadilan

Definisi keadilan dapat dipahami sebagai suatu nilai (value) yang digunakan untuk menciptakan hubungan yang seimbang antar manusia dengan memberikan apa yang menjadi hak seseorang dengan prosedur dan bila terdapat pelanggaran terkait keadilan maka seseorang perlu diberikan hukuman. Salah satu asas dalam hukum yang mencerminkan keadilan yaitu asas equality before the law yaitu asas yang menyatakan bahwa semua orang sama kedudukannya dalam hukum. ${ }^{6}$

Keadilan menurut hukum atau yang sering dimaksud dalam keadilan hukum (legal justice) adalah keadilan menurut undang-undang dan berkenaan dengan pemberian sanksi atas hasil penerapan undang-undang yang dilanggar. Hal ini menunjukkan bahwa jika seseorang telah melanggar keadilan tersebut, maka akan dikenakan hukuman lewat proses hukum. ${ }^{7}$

Hukum diciptakan agar setiap individu anggota masyarakat dan penyelenggara negara melakukan sesuatu tindakan yang diperlukan untuk menjaga tatanan sosial dan mencapai tujuan kehidupan bersama atau

\footnotetext{
hlm. 21.

${ }^{3}$ Koentjaraningrat, Metode-Metode Penelitian Masyarakat, Gramedia Pustaka Utama,

${ }^{4}$ Oemar Seno Adji, Prasarana Dalam Indonesia Negara Hukum, Simposium UI Jakarta, 1966, hlm. 24.

${ }_{5}^{5}$ Https://id.wikipedia.org/wiki/Negara_hukum di akses pada tanggal 31 Oktober 2019.

${ }^{6}$ Munir Fuady, Dinamika Teori Hukum, Ghalia Indonesia, Bogor, 2010, hlm. 91.

${ }^{7}$ I Dewa Gede Atmadja, Filsafat Hukum, Setara Press, Malang, 2013, hlm. 87.
} 
PRESUMPTION of LAW

Fakultas Hukum Universitas Majalengka

Volume 3 Nomor 2 Oktober 2021

sebaliknya agar tidak melakukan suatu tindakan yang dapat merusak tatanan keadilan. Setiap pelanggaran akan mendapatkan sanksi sesuai dengan tingkat pelanggaran itu sendiri. Hukum mewujudkan sebuah nilai karena ia merupakan sebuah norma. Hukum mewujudkan tatanan nilai sekaligus nilai moral, dan itu hanya bermakna bilamana hukum dipandang sebagai sebuah norma. ${ }^{8}$

3. Teori Kedisiplinan

Disiplin adalah sistem ajaran mengenai kenyataan atau gejala-gejala yang dihadapi. Dalam hal ini hukum dalam arti disiplin melihat hukum sebagai gejala dan kenyataan yang ada di tengah masyarakat. Apabila pembicaraan dibatasi pada disiplin hukum, maka secara umum disiplin hukum menyangkut ilmu hukum, politik hukum dan filsafat hukum.

a. Ilmu hukum, intinya merupakan ilmu pengetahuan yang berusaha menelaah hukum.

b. Politik hukum, mencakup kegiatan-kegiatan mencari dan memilih nilainilai dan menerapkan nilai-nilai tersebut bagi hukum dalam mencapai tujuannya.

c. Filsafat hukum, adalah perenungan dan perumusan nilai-nilai, juga mencakup penyesuaian nilai-nilai, misalnya penyerasian antara ketertiban dengan ketentraman, antara kebendaan dengan keakhlakan, dan antara kelanggengan dengan pembaharuan. ${ }^{9}$

Sebagimana telah dikemukakan di atas, disiplin hukum merupakan sistem ajaran yang menyangkut kenyataan atau gejala-gejala hukum yang ada dan hidup di tengah pergaulan masyarakat.

Kedisiplinan merupakan suatu hal yang sangat mutlak dalam kehidupan manusia, karena seorang manusia tanpa disiplin yang kuat akan merusak sendi-sendi kehidupannya, yang akan membahayakan dirinya dan manusia lainnya, bahkan alam sekitarnya.

Disiplin merupakan tatanan keteraturan dalam bersikap, berpola dan perilaku yang didasari oleh kesadaran dan keinsyafan pribadi. Disiplin dari kata discere dapat diartikan sebagai tingkah laku yang bersesuaian dengan aturan-aturan perilaku dalam suatu kelompok tertentu. Dalam pengertian lain, disiplin dapat dimaknai sebagai kepatuhan terhadap peraturan atau sikap batin yang bertujuan mengembangkan diri agar dapat berperilaku dengan benar dan tertib.

Dalam organisasi militer, permasalahan kedisiplinan merupakan hal pokok yang sangat mendasar, sehingga karenanya pengaturan tentang disiplin dinormakan dalam bentuk undang-undang. Sebagai norma dasar kemiliteran, hukum disiplin militer tidak hanya norma tertulis saja, tetapi juga didalamnya terdapat nilai-nilai tidak tertulis yang dijadikan landasan kehidupan militer.

${ }^{8}$ Hans Kelsen, Teori Hukum Murni, Nusa Media, Penerjemah: Raisul Mutaqien, Bandung, 2014, hlm. 75.

${ }^{9}$ Soedjono Dirdjosisworo, Pengantar Ilmu Hukum, PT. Raja Grafindo Persada, Jakarta, hlm. 43. 
Disiplin militer mengatur dan mengarahkan agar seorang Militer selalu berada pada tatanan budaya hukum dan mekanisme perilaku yang berlaku di lingkungan militer, terutama dalam menjaga keseimbangan antara hak dan kewajiban pada satu sisi, dan kepentingan tugas-tugas kemiliteran pada sisi lainnya. Keseimbangan ini melahirkan pemahaman yang bersifat kultural, bahwa mekanisme kehidupan dalam kemiliteran dijalankan atas keteraturan norma-norma yang telah melembaga sebagai bentuk pengakuan dan penghormatan terhadap supremasi hukum. Pada akhirnya kedisiplinan ini diharapkan mampu untuk menjauhkan diri dari sikap dan perilaku arogan serta rasa superior atas komponen bangsa lainnya. ${ }^{10}$

4. Teori Hukum Pembangunan

Teori Hukum Pembangunan Mochtar Kusumaatmadja memakai kerangka acuan pada pandangan hidup masyarakat serta bangsa Indonesia yang meliputi struktur, kultur, dan substansi, yang sebagaimana dikatakan oleh Lawrence F. Friedman. Pada dasarnya memberikan dasar fungsi, hukum sebagai sarana pembaharuan masyarakat, dan hukum sebagai suatu sistem yang sangat diperlukan bagi bangsa Indonesia sebagai Negara yang sedang berkembang.

Menurut Mochtar Kusumaatmadja, hukum diharapkan agar berfungsi lebih daripada itu yakni sebagai "sarana pembaharuan masyarakat" dengan pokok-pokok pikiran sebagai berikut :

"Hukum merupakan sarana pembaharuan masyarakat didasarkan kepada anggapan bahwa adanya keteraturan atau ketertiban dalam usaha pembangunan dan pembaharuan itu merupakan suatu yang diinginkan atau dipandang (mutlak) perlu. Anggapan lain yang terkandung dalam konsepsi hukum sebagai sarana pembaharuan adalah bahwa hukum dalam arti kaidah atau peraturan hukum memang bisa berfungsi sebagai alat (pengatur) atau sarana pembangunan dalam arti penyalur arah kegiatan manusia ke arah yang dikehendaki oleh pembangunan dan pembaharuan". ${ }^{11}$

Berpijak pada Teori Hukum Pembangunan Mochtar Kusumaatmadja bahwa peranan hukum bisa menjadi alat yang bersifat memaksa untuk perubahan yang lebih baik di masyarakat, sehingga siapapun pelaku pelanggaran termasuk anggota Tentara Nasional Indonesia terhadap peraturan yang ada bisa secara paksa untuk melakukan perubahan kearah yang lebih baik.

\section{E. Metode Penelitian}

Penelitian dipandang sebagai kegiatan formal, sebuah prosedur baku, yang (secara umum) dikatakan sebagai alat pencari data melalui suatu proses untuk menambah pengetahuan pada kerangka pengetahuan seseorang, dan diharapkan juga terjadi pada orang lain, lewat penemuan fakta dan wawasan

${ }^{10}$ A.S.S. Tambunan, Hukum Disiplin Militer Suatu Kerangka Teori, Pusat Studi Hukum Militer, STHM, Jakarta, 2013, hlm. 55.

${ }_{11}$ Yuoky Surinda, https://yuokysurinda.wordpress.com/2016/02/27/ teori-hukumpembangunan-mochtar-kusumaatmadja 
yang sesungguhnya. Untuk dapat mengetahui dan membahas suatu permasalahan maka diperlukan adanya pendekatan dengan menggunakan metode-metode tertentu yang bersifat ilmiah.

Menurut Soerjono Soekanto mengatakan bahwa :

Penelitian hukum merupakan suatu kegiatan ilmiah, yang didasarkan pada metode, sistematika, dan pemikiran tertentu, yang bertujuan untuk mempelajari suatu atau bebrapa gejala hukum tertentu, dengan jalan penganalisanya. Di samping itu, juga diadakan pemeriksaan yang mendalam terhadap fektor hukum tersebut, untuk kemudian mengusahakan suatu pemecahan atas permasalahan yang timbul didalam gejala yang bersangkutan. ${ }^{12}$

Metode penelitian yang akan digunakan untuk penulisan ini adalah sebagai berikut :

1. Spesifikasi Penelitian

Dalam penulisan usulan penelitian ini menggunakan spesifikasi penelitian deskriptif analisis untuk menuliskan fakta dan memperoleh gambaran berdasarkan judul dan identifikasi masalah, yang menggambarkan peraturan perundang-undangan yang berlaku dikaitkan dengan teori hukum dan praktek pelaksanaan yang menyangkut permasalahan dalam uraian diatas secara sistematis, lengkap dan logis. ${ }^{13}$

2. Metode Pendekatan

Metode pendekatan yang akan digunakan dalam penelitian ini adalah pendekatan yuridis empirik. yaitu hukum sebagai gejala masyarakat, sebagai institusi sosial atau prilaku yang mempola. Pendekatan ini dikenal dengan penelitian hukum sosiologis. ${ }^{14}$

Termasuk kedalam pendekatan yang dapat dikategorikan yuridis empirik antara lain antara lain misalnya, pedekatan yuridis kriminologis, yuridis psikologis, yuridis ekonomis dan lain-lain. Pendekatan empirik terkadang juga dapat bersifat internal dan multi disipliner.

3. Tahap Penelitian

Tahap penelitian yang digunakan yaitu studi pustaka (literatur/dokumen) dan penelitian lapangan.

a. Studi pustaka

Yaitu penelitian yang dilakukan untuk mendapatkan data yang bersifat teoritis, dengan mempelajari sumber-sumber bacaan yang berisikan berbagai pengertian dan pendapat para ahli yang erat hubunganya dengan permasalahan dalam penelitian ini.

b. Penelitian lapangan

Penelitian lapangan dimaksudkan untuk memperoleh informasi yang dibutuhkan untuk melengkapi data-data studi pustaka. Data yang

\footnotetext{
${ }^{12}$ Zainuddin Ali, Metode Penelitian Hukum, Sinar Grafika, Jakarta, 2014, hlm 18

${ }^{13}$ Danny Rahadian, Implementasi Penegakan Hukum Pidana, Skripsi, Fakultas Hukum Universitas Majalengka, hlm. 14.

14 Panduan Skripsi, Fakultas Hukum universitas Majalengka, Cetakan Kesembilan 2021, hlm. 19.
} 
PRESUMPTION of LAW

Fakultas Hukum Universitas Majalengka

Volume 3 Nomor 2 Oktober 2021

diperoleh dari penelitian lapangan ini berupa wancara dari polres Majalengka.

4. Teknik Pengumpulan Data

Teknik pengumpulan data yang digunakan adalah studi kepustakaan dan observasi langsung.

a. Studi kepustakaan

Teknik ini dilakukan untuk mendapatkan data yang bersifat teoritis, dengan cara inventarisasi data melalui tahap mengumpulkan, mengolah, dan memilih data. Teknik ini juga digunakan untuk memberi arahan dengan mempelajari masalah yang diteliti dari buku-buku, majalah, dan koran yang ada hubungannya dengan masalah yang diteliti.

b. Observasi langsung

Teknik ini dilakukan untuk mengumpulkan, meneliti dan mengolah data yang diperoleh dari lapangan dengan melakukan observasi secara langsung terhadap objek yang diteliti.

5. Alat Pengumpulan Data

Alat pengumpulan data yang digunakan penulis adalah observasi dan wawancara, yaitu melakukan penelitian di Polres Majalengka serta juga melakukan tanya jawab untuk mendapatkan data secara langsung dari responden yang terkait dengan masalah.

6. Analisis Data

Analisis data yang digunakan dalam penelitian ini adalah yuridis kualitatif yang bertujuan untuk menggambarkan tinjauan kriminologi dan viktimologi terhadap kasus tindak pidana pedofilia berdasarkan peraturan pemerintah pengganti Undang-Undang Nomor 1 tahun 2016 Tentang perlindungan anak.

7. Lokasi Penelitian

Dalam penyusunan Seminar Hasil Penelitian Skripsi ini berlokasi di tempat yang mempunyai korelasi dengan masalah yang dikaji oleh peneliti, yaitu :

a. Perpustakaan Universitas Majalengka

b. Perpustakaan Fakultas Hukum Universitas Majalengka

c. Perpustakaan Daerah Kabupaten Majalengka

d. Polres Majalengka, Jl.Raya K H Abdul Halim No.518, Tonjong, Kec.

Majalengka, Kab. Majalengka Jawa Barat 45414

8. Jadwal Penelitaian

Adapun jadwal penelitian yang akan berlangsung mulai bulan April 2021 sampai dengan bulan Agustus 2021, yang dijelaskan dalam tabel di bawah ini: 
PRESUMPTION of LAW Fakultas Hukum Universitas Majalengka

Volume 3 Nomor 2 Oktober 2021

\begin{tabular}{|c|c|c|c|c|c|c|c|c|c|c|c|c|c|c|c|c|c|c|}
\hline \multirow{4}{*}{ No } & \multirow{4}{*}{ Uraian } & \multicolumn{17}{|c|}{ Tahun 2021} \\
\hline & & \multicolumn{3}{|c|}{ April } & \multicolumn{3}{|c|}{ Mei } & \multicolumn{4}{|c|}{ Juni } & \multirow{2}{*}{\multicolumn{4}{|c|}{ Juli }} & \multicolumn{3}{|c|}{ Agustus } \\
\hline & & \multicolumn{13}{|c|}{ Minggu Ke } & & & & \\
\hline & & 3 & 4 & 1 & 2 & 3 & 4 & 1 & 2 & 3 & 4 & 1 & 2 & 3 & 4 & 1 & 2 & 3 \\
\hline 1 & $\begin{array}{l}\text { Pengajuan Judul } \\
\text { Penelitian Skripsi }\end{array}$ & & & & & & & & & & & & & & & & & \\
\hline 2 & $\begin{array}{l}\text { Bimbingan Usulan } \\
\text { Penelitian Skripsi }\end{array}$ & & & & & & & & & & & & & & & & & \\
\hline 3 & $\begin{array}{l}\text { Seminar Usulan } \\
\text { Penelitian Skripsi }\end{array}$ & & & & & & & & & & & & & & & & & \\
\hline 4 & $\begin{array}{ll}\text { Revisi Usulan } & \text { Unelitian Skrinsi }\end{array}$ & & & & & & & & & & & & & & & & & \\
\hline 5 & $\begin{array}{ll}\text { Pengumpulan } & \text { dan } \\
\text { Pengolahan Data } & \end{array}$ & & & & & & & & & & & & & & & & & \\
\hline 6 & $\begin{array}{l}\text { Bimbingan Hasil } \\
\text { Penelitian Skripsi }\end{array}$ & & & & & & & & & & & & & & & & & \\
\hline 7 & $\begin{array}{l}\text { Seminar Hasil } \\
\text { Penelitian Skripsi }\end{array}$ & & & & & & & & & & & & & & & & & \\
\hline 8 & $\begin{array}{l}\text { Revisi Hasil Penelitian } \\
\text { Skripsi }\end{array}$ & & & & & & & & & & & & & & & & & \\
\hline 9 & Bimbingan Skripsi & & & & & & & & & & & & & & & & & \\
\hline 10 & Sidang Skripsi & & & & & & & & & & & & & & & & & \\
\hline
\end{tabular}

F. Pembahasan Analisis Kriminologi Dan Viktimologi Terhadap Kasus Tindak Pidana Pedofilia.

\section{Penegakan Hukum Terhadap Pelaku Tindak Pidana Pedofilia.}

Secara kosepsional, maka inti dari penegakan hukum terletak pada kegiatan menyerasikan hubungan nilai-nilai yang terjabarkan di dalam kaidah-kaidah yang mantap dan mengejawantah dan sikap tindak sebagai rangkaian penjabaran nilai tahap akhir, untuk menciptakan, memelihara dan mempertahankan kedamaian pergaulan hidup konsepsi yang mempunyai dasar filosofis tersebut, memerlukan penjelasan lebih lanjut sehingga akan tampak lebih konkret.

Penegakan hukum merupakan salah satu persoalan yang serius bagi bangsa Indonesia. penegakan hukum sebagai usaha semua kekuatan bangsa, menjadi kewajiban kolektif semua komponen bangsa. Hukum bagi kita adalah suatu yang bersifat Supreme atau yang paling tinggi di antara lembaga-lembaga tinggi negara lainnya. dari konsepsi demikian maka tumbuhlah kesadaran manusia pemuja keadilan istilah supremasi hukum di mana hukum ditempatkan pada yang tertinggi di antara dimensi-dimensi kehidupan yang lain, terutama dimensi politik.

${ }^{15}$ Penegakan hukum ditujukan guna meningkatkan ketertiban dan kepastian hukum dalam masyarakat. Hal ini dilakukan antara lain dengan menertibkan fungsi, tugas dan wewenang lembaga-lembaga yang bertugas menegak- kan hukum menurut proporsi ruang lingkup masing-masing, serta

\footnotetext{
${ }^{15}$ Ilham Bisri, Sistem Hukum Indonesia, Rajawali Pers, Jakarta, 2013. hlm. 129.
} 
PRESUMPTION of LAW

Fakultas Hukum Universitas Majalengka

Volume 3 Nomor 2 Oktober 2021

didasarkan atas sistem kerjasama yang baik dan mendukung tujuan yang hendak dicapai. Tingkat perkembangan masyarakat tempat hukum diberlakukan mempengaruhi pola penegakan hukum, karena dalam masyarakat modern yang bersifat rasional dan memiliki tingkat spesialisasi dan differensiasi yang tinggi penggorganisasian penegak hukumnya juga semakin kompleks dan sangat birokratis.

Kajian secara sistematis terhadap penegakan hukum dan keadilan secara teoritis dinyatakan efektif apabila 5 pilar hukum berjalan baik yakni: instrument hukumnya,aparat penegak hukumnya, faktor warga masyarakatnya yang terkena lingkup peraturan hukum, faktor kebudayaan atau legal culture, factor sarana dan fasilitas yang dapat mendukung pelaksanaan hukum. ${ }^{16}$

Penegakan hukum adalah proses dilakukannya upaya untuk tegaknya atau berfungsinya norma-norma hukum secara nyata sebagai pedoman perilaku dalam lalu lintas atau hubungan-hubungan hukum dalam kehidupan bermasyarakat dan bernegara. Ditinjau dari sudut subjeknya, penegakan hukum itu dapat dilakukan oleh subjek yang luas dan dapat pula diartikan sebagai upaya penegakan hukum oleh subjek dalam arti yang terbatas atau sempit.

Dalam arti luas, proses penegakan hukum itu melibatkan semua subjek hukum dalam setiap hubungan hukum. Siapa saja yang menjalankan aturan normatif atau melakukan sesuatu atau tidak melakukan sesuatu dengan mendasarkan diri pada norma aturan hukum yang berlaku, berarti dia menjalankan atau menegakkan aturan hukum. Dalam arti sempit, dari segi subjeknya itu, penegakan hukum itu hanya diartikan sebagai upaya aparatur penegakan hukum tertentu untuk menjamin dan memastikan bahwa suatu aturan hukum berjalan sebagaimana seharusnya. Dalam memastikan tegaknya hukum itu, apabila diperlukan, aparatur penegak hukum itu diperkenankan untuk menggunakan daya paksa.

Menurut Soerjono Sukanto ada 2 faktor yang mempengaruhi penegakan hukum yaitu :

1. Faktor masyarakat

Penegakan hukum berasal dari masyarakat, dan bertujuan untuk mencapai kedamaian di dalam masyarakat. Oleh karena itu, dipandang dari sudut tertentu, maka masyarakat dapat mempengaruhi penegakan hukum tersebut. di dalam bagian ini, diketengahkan secara garis besar perihal pendapat-pendapat masyarakat mengenai hukum, yang sangat mempengaruhi kepatuhan hukumnya.

2. Faktor Kebudayaan

Faktor kebudayaan yang sebenarnya bersatu padu dengan faktor masyarakat sengaja dibedakan, karena di dalam pembahasannya diketengahkan masalah sistem nilai-nilai yang menjadi inti dari kebudayaan spiritual atau non materiel. Sebagai suatu sistem maka

${ }^{16}$ Sanyato, Penegakan Hukum Di Indonesia, Jurnal Dinamika Hukum, Volume 8 Nomor 3 Fakultas Hukum Universitas Jendral Soedirman, Purwokerto, tahun 2008 
hukum mencakup struktur, subtansi, kebudayaan. ${ }^{17}$

Pengertian penegakan hukum itu dapat pula ditinjau dari sudut objeknya, yaitu dari segi hukumnya. Dalam hal ini, pengertiannya juga mencakup makna yang luas dan sempit. Dalam arti luas, penegakan hukum itu mencakup pula nilai-nilai keadilan yang terkandung di dalamnya bunyi aturan formal maupun nilai-nilai keadilan yang hidup dalam masyarakat. Tetapi, dalam arti sempit, penegakan hukum itu hanya menyangkut penegakan peraturan yang formal dan tertulis saja.

Karena itu, penerjemahan perkataan 'law enforcement' ke dalam bahasa Indonesia dalam menggunakan perkataan 'penegakan hukum' dalam arti luas dan dapat pula digunakan istilah 'penegakan peraturan' dalam arti sempit. Pembedaan antara formalitas aturan hukum yang tertulis dengan cakupan nilai keadilan yang dikandungnya ini bahkan juga timbul dalam bahasa Inggeris sendiri dengan dikembangkannya istilah 'the rule of law' versus 'the rule of just law' atau dalam istilah 'the rule of law and not of man' versus istilah 'the rule by law' yang berarti 'the rule of man by law'. 18

Dalam istilah 'the rule of law' terkandung makna pemerintahan oleh hukum, tetapi bukan dalam artinya yang formal, melainkan mencakup pula nilai-nilai keadilan yang terkandung di dalamnya. Karena itu, digunakan istilah 'the rule of just law'. Dalam istilah 'the rule of law and not of man' dimaksudkan untuk menegaskan bahwa pada hakikatnya pemerintahan suatu negara hukum modern itu dilakukan oleh hukum, bukan oleh orang. Istilah sebaliknya adalah 'the rule by law' yang dimaksudkan sebagai pemerintahan oleh orang yang menggunakan hukum sekedar sebagai alat kekuasaan belaka.

Dengan uraian di atas jelaslah kiranya bahwa yang dimaksud dengan penegakan hukum itu kurang lebih merupakan upaya yang dilakukan untuk menjadikan hukum, baik dalam arti formil yang sempit maupun dalam arti materiel yang luas, sebagai pedoman perilaku dalam setiap perbuatan hukum, baik oleh para subjek hukum yang bersangkutan maupun oleh aparatur penegakan hukum yang resmi diberi tugas dan kewenangan oleh undang-undang untuk menjamin berfungsinya norma-norma hukum yang berlaku dalam kehidupan bermasyarakat dan bernegara.

Dari pengertian yang luas itu, pembahasan kita tentang penegakan hukum dapat kita tentukan sendiri batas-batasnya. Apakah kita akan membahas keseluruhan aspek dan dimensi penegakan hukum itu, baik dari segi subjeknya maupun objeknya atau kita batasi hanya membahas hal-hal tertentu saja, misalnya, hanya menelaah aspek-aspek subjektifnya saja. Skripsi ini memang sengaja dibuat untuk memberikan gambaran saja mengenai keseluruhan aspek yang terkait dengan tema penegakan

17 Soerjono Soekanto, Faktor-Faktor Yang Mempengaruhi Penegakan Hukum, Raja wali Pers, Jakarta, 2016, hlm.45,59.

${ }^{18}$ Jimly Asshiddqie, Penegakan Hukum, www.jimly.com di akses pada tanggal 9 Juni 2021 
hukum itu.

Seperti disebut di muka, secara objektif, norma hukum yang hendak ditegakkan mencakup pengertian hukum formal dan hukum materiel. Hukum formal hanya bersangkutan dengan peraturan perundang-undangan yang tertulis, sedangkan hukum materiel mencakup pula pengertian nilai-nilai keadilan yang hidup dalam masyarakat. Dalam bahasa yang tersendiri, kadang-kadang orang membedakan antara pengertian penegakan hukum dan penegakan keadilan.

Penegakan hukum dapat dikaitkan dengan pengertian 'law enforcement' dalam arti sempit, sedangkan penegakan hukum dalam arti luas, dalam arti hukum materiel, diistilahkan dengan penegakan keadilan. Dalam bahasa Inggeris juga terkadang dibedakan antara konsepsi 'court of law' dalam arti pengadilan hukum dan 'court of justice' atau pengadilan keadilan. Bahkan, dengan semangat yang sama pula, Mahkamah Agung di Amerika Serikat disebut dengan istilah 'Supreme Court of Justice'.

Istilah-istilah itu dimaksudkan untuk menegaskan bahwa hukum yang harus ditegakkan itu pada intinya bukanlah norma aturan itu sendiri, melainkan nilai-nilai keadilan yang terkandung di dalamnya. Memang ada doktrin yang membedakan antara tugas hakim dalam proses pembuktian dalam perkara pidana dan perdata. Dalam perkara perdata dikatakan bahwa hakim cukup menemukan kebenaran formil belaka, sedangkan dalam perkara pidana barulah hakim diwajibkan mencari dan menemukan kebenaran materiel yang menyangkut nilainilai keadilan yang harus diwujudkan dalam peradilan pidana. ${ }^{19}$

2. Penegakan Hukum Tindak Pidana Pedofilia Berdasarkan Kitab Undang-Undang Hukum Pidana.

Berikut ini meliputi pengaturan tindak pidana pedofilia yang dapat digunakan untuk menjerat pelaku pelecehan seksual pada anak termasuk para pedofilia di Indonesia berdasarkan Hukum Pidana Indonesia

a. Dalam Kitab Undang-Undang Hukum Pidana (KUHP)

1) Pasal 29 KUHP

"Barang siapa dengan kekerasan atau ancaman kekerasan memaksa seseorang untuk melakukan atau membiarkan dilakukannya perbuatan cabul, diancam karena melakukan perbuatan yang menyerang kehormatan, kesusilaam, dendam pidana penjara paling lama Sembilan tahun".

2) Pasal 290 ayat (2) KUHP

"Diancam dengan pidana penjara paling lama tujuh tahun; barang siapa melakukan perbuatan cabul dengan seseorang padahal diketahuinya atau sepatuhnya harus diduganya bahwa umumnya belum lima belas tahun atau kalau umumnya tidak jelas, bahwa yang bersangkutan belum masanya untuk dikawini."

\footnotetext{
${ }^{19}$ Ibid, hlm.61.
} 
3) Pasal 290 ayat (3) KUHP

"Diancam dengan pidana penjara paling lama tujuh tahun: "Barang siapa membujuk (menggoda) seseorang yang diketahuinya atau patut harus disangkanya bahwa umur orang itu belum cukup lima belas tahun atau kalau tidak nyata berapa umurnya, bahwa ia belum mampu dikawini, untuk melakukan atau membiarkan perbuatan cabul atau bersetubuh di luar perkawinan dengan orang lain."

4) Pasal 292 KUHP

5) "Orang dewasa yang melakukan perbuatan cabul dengan orang lain sesama kelamin, yang diketahuinya atau sepatutnya harus diduganya belum dewasa, diancam pidana penjara paling lama lima tahun."

6) Pasal 293 ayat (1) KUHP

"Barang siapa dengan memberi atau menjanjikan uang atau barang, dengan menyalahgunakan perbawa yang timbul dari hubungan keadaan, atau dengan penyesatan sengaja menggerakkan seorang belum dewasa dan baik tingkah lakunya untuk melakukan atau membiarkan dilakukannya perbuatan cabul dengan dia, padahal belum cukup umurnya atau selayaknya diduganya belum cukup umur, diancam dengan pidana penjara paling lama lima tahun."

7) Pasal 294 ayat (1) KUHP

"Barang siapa melakukan perbuatan cabul dengan anaknya, anak tirinya, anak angkatnya, anak di bawah pengawasannya yang belum dewasa, yang pemeliharanya, pendidikan atau penjagaannya diserahkan kepada ataupun dengan bujangnya atau bawahannya yang belum dewasa, diancam dengan pidana penjara paling lama tujuh tahun."

Kebijakan pemidanaan bagi pelaku pedofilia dalam hukum positif Indonesia pada dasarnya memiliki tujuan pemidanaan yakni : untuk memperbaiki pribadi dan penjahat itu sendiri, untuk membuat orang menjadi jera, untuk membuat penjahat-penjahat tertentu menjadi tidak mampu untuk melakukan kejahatan lain, didalam hukum positif Indonesia pemidanaan pelaku pedofilia sudah diatur di dalam Kitab Undang-Undang Hukum Pidana sebagai peraturan umum dan Peraturan Pemerintah Pengganti Undang-Undang Nomor 1 Tahun 2016 tentang perubahan kedua atas Undang-Undang Nomor 23 Tahun 2002 Tentang Perlindungan Anak sebagai peraturan khusus.

\section{Faktor-Faktor Yang Menyebabkan Terjadinya Tindak Pidana Pedofilia.}

Perilaku seksual adalah bermacam-macam dan ditentukan oleh suatu interaksi faktor-faktor yang kompleks. Perilaku seksual dipengaruhi oleh hubungan seseorang dengan orang lain, oleh lingkungan seseorang dan oleh kultur dimana seseorang tinggal. Seorang dokter harus mengetahui beragam variasi tentang perilaku seksual dalam lingkungan sosial, sehubungan dengan perilaku tersebut, dimana ada 2 alasan untuk itu. Pertama; pengetahuan tersebut membantu dokter untuk tidak memaksakan 
PRESUMPTION of LAW

Fakultas Hukum Universitas Majalengka

Volume 3 Nomor 2 Oktober 2021

perilakunya sendiri terhadap pasiennya. Kedua; membantu dokter mengenali beberapa perilaku seks yang abnormal.

Kelainan seksual adalah cara yang ditempuh seseorang untuk mendapatkan kenikmatan seksual dengan jalan tidak sewajarnya. Biasanya, cara yang digunakan oleh orang tersebut adalah dengan menggunakan objek seks yang tidak wajar. Penyebab terjadinya kelainan ini bersifat psikologis atau kejiwaan, seperti pengalaman sewaktu kecil, lingkungan pergaulan, trauma dan kelainan genetika. Pedofilia sendiri sudah menjadi jaringan internasional dan Indonesia merupaka salah satu daerah tujuan kaum pedofilia. Faktor-faktor penyebab kenapa Indonesia menjadi sasaran kaum pedofilia adalah sebagai berikut :

1. Lemahnya hukum perlindungan anak dan penegakannya di Indonesia, misalnya dalam KUHP bagi pelaku pelecehan seksual terhadap anak di hukum maksimal penjara 9 (Sembilan) tahun kemudian dengan adanya UU Perlindungan Anak di hukum 15 (lima belas) tahun sedangkan di Filipina bagi pelaku pelecehan seksual terhadap anak di hukum mati.

2. Lemahnya perangkat keamanan di Indonesia dalam membendung aksi para pedofilia yang kian canggih, kaum pedofilia menggunakan fasilitas internet untuk mencari mangsanya.

3. Faktor kemiskinan di Indonesia yang kini semakin buruk membuat anakanak kian rentan terhadap beberapa bentuk kejahatan dan eksploitasi. ${ }^{20}$

Keterangan tentang trauma psikis yang diderita korban kasus pedofilia seperti dijelaskan, korban mengalami berbagai gangguan seperti mudah marah, susah tidur, dan sering mengigau, cenderung mengasingkan diri dari pergaulan teman sebaya, dan sebagainya-menunjukkan perlunya program pendampingan khusus terhadap anak-anak korban kejahatan seksual dengan upaya sosialisasinya yang lebih luas, termasuk pendampingan khusus bagi korban dari kalangan anak laki-laki.

Kejahatan seksual biasanya diidentikkan dengan korban kalangan wanita dan anak-anak perempuan sehingga beberapa program pendampingan, seperti yang dilaksanakan beberapa crisis center yang berkembang di Indonesia akhir- akhir ini, sering disalahartikan hanya untuk wanita dan anak-anak perempuan, bukan untuk anak laki-laki. Upaya pendampingan terhadap anak laki-laki korban kejahatan seksual sendiri relatif lebih sulit untuk dilaksanakan dibanding program untuk anak perempuan. Faktor budaya di sebagian masyarakat kita masih menjadi hambatan besar bagi anak laki-laki untuk mengungkap kasusnya.

Pedofilia adalah gangguan seksual yang berupa nafsu seksual terhadap remaja atau anak-anak di bawah usia 14 tahun. Orang yang mengidap pedofilia disebut pedofil. Seseorang bisa dianggap pedofil jika usianya minimal 16 tahun. Menurut media massa, pedofilia lebih dikenal sebagai aksi pelecehan anak. Definisi ini kurang tepat dan tidak akurat dalam menggambarkan situasi pasien yang menyebabkan kesulitan pada penelitian dan pengumpulan data penyakit ini.

\footnotetext{
${ }^{20}$ Ibid, hlm.63.
} 
PRESUMPTION of LAW

Fakultas Hukum Universitas Majalengka

Volume 3 Nomor 2 Oktober 2021

Penting untuk diketahui bahwa pedofilia adalah penyakit, bukan dosa. Tidak semua pedofil melakukan pelecehan pada anak, dan tentunya tidak semua orang yang melakukan kekerasan seksual pada anak-anak merupakan pedofil. Pedofilia biasanya terdeteksi oleh diri sendiri setelah masa puber, saat orientasi seksual seseorang terfokus pada anak-anak, bukan orang dewasa. Ia tidak dapat menentukan orientasi seksual mereka dan kemudian merasa takut akan diri mereka sendiri. ${ }^{21}$

Mereka juga sering mengalami diskriminasi social, sulit bagi mereka untuk terlibat dalam komunitas dan berhubungan dengan orang lain. Ini membuatnya tertarik pada anak-anak karena mereka tergolong masih polos dan tidak menghakimi seperti orang dewasa. Belakangan ini, para ilmuwan dan masyarakat memiliki kecenderungan untuk mempelajari masalahmasalah psikologis; beberapa pasien lebih terbuka akan penyakit mereka demi ilmu pengetahuan. Menurut para pasien, gejala pedofilia di antara lain perasaan inferior, terisolasi, dan bahkan depresi; mereka takut orientasi seksual mereka diketahui, jadi mereka mengisolasi diri dari orang lain. Para pasien menganggap gairah mereka salah dan illegal untuk dipenuhi. Maka dari itu mereka selalu mengontrol diri mereka sendiri dan mencari cara aman untuk memuaskan diri sendiri.

Beberapa kasus dari kekerasan pada anak-anak sering melibatkan penyakit kejiwaan yang lain seperti schizophrenia dan distorsi-distorsi kognitif. Di sisi lain, beberapa kasus kriminal pada anak sebenarnya bukan merupakan pedofilia. Pasien dapat mengidap penyakit kejiwaan lain seperti kecemasan, depresi parah, gangguan suasana hati, dan penggunaan stimulan yang berlebihan.

Penyebab pedofilia masih belum dapat diketahui dengan jelas karena penyakit psikologis hanya baru-baru ini dipelajari lebih lanjut. Kesulitan untuk menentukan penyebab yang pasti juga didasari oleh perbedaan karakteristik dan latar belakang pada setiap orang. Banyak ahli berasumsi bahwa penyebab utama datang dari faktor psikologi sosial, bukan biologis. Beberapa dokter menyatakan bahwa faktor yang mempengaruhi kepribadian pasien adalah latar belakang keluarga yang tidak normal. Dilecehkan pada usia dini juga dapat menjadi penyebabnya. Namun demikian, angka kasus ini tidak banyak, sehingga tidak pasti menyebabkan pedofilia.

Penyebab pedofilia tidak diketahui secara pasti. Namun para pakar menduga bahwa beberapa faktor berikut ini bisa memengaruhi risiko kemunculan pedofilia :

a. Hubungan keluarga yang tidak harmonis, misalnya perceraian orangtua

b. Riwayat sebagai korban kekerasan seksual saat masih berusia kanakkanak

c. Gangguan kepribadian antisosial

d. Kecanduan obat-obatan

${ }^{21}$ Lika aprilia samiadi, Prdofilia : Penyebab, Resiko, Pengobatan, hellosehat.com, diakses pada tanggal 10 Juni 2021 
e. Depresi

f. Faktor genetik

g. Faktor lingkungan, yang membuat penderita perilakunya dari orang lain, referensi bacaan, atau tontonan yang berkaitan dengan pedofilia

h. Ketidakseimbangan hormon dan IQ yang rendah ${ }^{22}$

\section{Perlindungan Terhadap Korban Tindak Pidana Pedofilia.}

Setiap terjadi kejahatan, mulai dari kejahatan ringan sampai dengan kejahatan berat, tentu korban akan mengalami penderitaan, baik yang bersifat meteriil maupun immateril. Secara teoritis, bentuk perlindungan terhadap korban kejahatan dapat diberikan dalam berbagai cara, tergantung pada penderitaan atau kerugian yang diderita korban. Sebagai contoh, untuk kerugian yang sifatnya mental atau psikis tentunya bentuk ganti rugi dalam bentuk materi atau uang tidaklah memadai apabila tidak disertai dengan upaya pemulihan mental korban. Sebaliknya apabila korban hanya menderita kerugian secara materiil pelayanan yang sifatnya psikis terkesan terlalu berlebihan. ${ }^{23}$

Perlindungan Hukum Menurut Undang-Undang Perlindungan Anak Dalam Undang-Undang Nomor 35 tahun 2014 tentang Perlindungan Anak mengatur tentang bentuk-bentuk perlindungan khusus yang dapat diberikan pada Anak yang menjadi korban kejahatan, korban kekerasan fisik dan seksual dan anak korban perlakuan salah seperti Korban Pedofilia.

Pasal 64 Undang-Undang Nomor 35 tahun 2014 tentang Perlindungan Anak Perlindungan khsusus bagi anak yang berhadapan dengan hukum sebagaimana dimaksud dalam Pasal 59 ayat (2) huruf b dilakukan melalui :

a. Perlakuan secara manusiawi dengan memperhatikan kebutuhan sesuai dengan umurnya;

b. Pemisahan dari orang dewasa;

c. Pemberian bantuan hukum dan bantuan lain secara efektif;

d. Pemberlakuan kegiatan rekreasional;

e. Pembebasan dari penyiksaan, penghukuman, atau perlakuan yang lain yang kejam, tidak manusiawi serta merendahkan martabat dan derajatnya;

f. Penghindaran dari penjatuhan pidana mati dan/atau pidana seumur hidup;

g. Penghindaran dari penangkapan, penahanan atau penjara, kecuali sebagai upaya terakhir dan dalam waktu yang paling singkat;

h. Pemberian keadilan di muka pengadilan Anak yang objektif, tidak memihak, dan dalam sidang yang tertutup untuk umum;

i. Penghindaran dari publikasi atau identitasnya;

j. Pemberian pendampingan Orang Tua/Wali dan orang yang dipercaya oleh Anak;

${ }^{22}$ Nurul Rafiqua, Pedofilia, https://www.sehatq.com/penyakit/pedofilia di akses pada Tanggal 20 Juli 2021

${ }^{23}$ Desita Rahma Setia Wati, Tinjauan Tentang Perlindungan Hukum, https:/core.ac.uk. di akses pada tanggal 1 Juli 2021. 
PRESUMPTION of LAW

Fakultas Hukum Universitas Majalengka

Volume 3 Nomor 2 Oktober 2021

k. Pemberian advokasi sosial;

1. Pemberian kehidupan pribadi;

m. Pemberian aksesibilitas, terutama bagi Anak Penyandang Disabilitas;

n. Pemberian Pendidikan;

o. Pemberian pelayanan kesehatan; dan

p. Pemberian hak lain sesuai dengan ketentuan peraturan perundangundangan.

Perlindungan hukum terhadap anak yang menjadi korban pedofil adalah sebagai berikut :

1) Konseling

Perlindungan ini pada umumnya diberikan kepada korban sebagai akibat munculnya dampak negatif yang sifatnya psikis dari suatu tindak pidana. Pemberian bantuan dalam bentuk konseling sangat cocok diberikan kepada korban kejahatan yang menyisakan trauma berkepanjangan sebagai upaya rehabilitasi, seperti pada kasus-kasus menyangkut kesusilaan seperti korban pedofilia.

Tindak pidana pedofilia tentu menimbulkan dampak negatif pada korbannya, seperti trauma. Anak korban pedofilia secara jangka pendek maupun jangka panjang dapat mengalami gangguan fisik dan mental. Selain menderita fisik korban juga menderita tekanan batin, seperti merasa kotor, berdosa, merasa berbeda dengan anak-anak lain. Usia anak yang sedang tumbuh dan berkembang seharusnya memerlukan stimulasi asah, asih dan asuh yang berkualitas dan berkesinambungan.

Bila pada periode ini anak mendapatkan trauma sebagai korban tindak pidana pedofilia, perkembangan moral, jiwa dan mentalnya akan terganggu. Terlebih bila perbuatan kejahatan tersebut disertai dengan paksaan dan kekerasan akan menimbulkan dampak yang lebih berat yang bisa terbawa hingga usia dewasa dan sulit dihilangkan, bahkan dapat menimbulkan gangguan kejiwaan dan mempunyai kecenderungan melakukan hal yang sama seperti apa yang pernah dialaminya, dengan kata lain korban dapat tertular perilaku pedofilia.

Anak adalah masa depan bangsa, jika anak korban pedofilia tidak ditangani dengan sungguh-sungguh maka masa depan bangsa juga akan menjadi suram. Dengan memperhatikan kondisi korban seperti diatas, upaya bantuan konseling ini sangat diperlukan, pendekatan psikoterapi sejak dini harus segera dilakukan untuk memulihkan kembali mental korban.

2) Pelayanan / Bantuan Medis

Korban pedofilia juga berhak mendapatkan pelayanan medis. Selain menderita secara mental korban tindak pidana pedofilia juga menderita fisik, misalnya luka akibat kekerasan seksual yang dialaminya. Pelayanan medis sebagai bentuk tanggung jawab pemerintah, baik rumah sakit yang ada, puskesmas-puskesmas yang memiliki pelayanan 24 jam setiap harinya, yang merupakan program pemerintah sebagai tanggung jawab pemerintah terhadap masyarakat.

Sehingga dalam konteks adanya kekerasan seksual yang terjadi 
PRESUMPTION of LAW

Fakultas Hukum Universitas Majalengka

Volume 3 Nomor 2 Oktober 2021

pihak rumah sakit atau puskesmas terdekat dapat memberikan pelayanan medis terhadap korban sebagai tindakan awal sebelum korban dirujuk pada pelayanan medis lainnya, apabila korban membutuhkan pelayanan medis lanjutan atau memerlukan perawatan yang intensif.

3) Bantuan Hukum

Bantuan hukum yang diberikan dapat berupa advokasi dan pendampingan kepada korban pedofilia. Bantuan hukum ini dapat dilakukan oleh pemerintah maupun lembaga- lembaga non pemerintah seperti Lembaga Swadaya Masyarakat (LSM). Upaya-upaya bantuan hukum ini diberikan dengan tujuan untuk memperjuangkan hak-hak anak korban tindak pidana kejahatan untuk mendapatkan perlindungan hukum. Pemberian bantuan hukum terhadap korban kejahatan harus diberikan baik diminta maupun tidak oleh korban. Hal ini penting, mengingat masih rendahnya tingkat kesadaran hukum dari sebagian korban kejahatan pedofilia.

Jika korban tindak pidana pedofilia dibiarkan begitu saja dan tidak diberi bantuan hukum yang layak, dapat berakibat semakin terpuruknya kondisi korban. Upaya perlindungan ini dapat dilakukan dengan cara memantau dan mengawai daerah-daerah yang rawan terjadi tindak pidana pedofilia. Yang bertugas melakukan pengawasan ini adalah pemerintah, lembaga-lembaga negara, lembaga-lembaga non pemerintah, keluarga dan masyarakat luas. Pegawasan oleh masyarakat terhadap anak punsangat penting dalam mencegah terjadinya tindak pidana kejahatan.

Sesuai dengan pasal 72 ayat (1) Undang-undang Perlindungan Anak bahwa masyarakat berperan serta dalam perlindungan anak baik secara perseorangan maupun kelompok. Masyarakat memperoleh kesempatan seluas-luasnya untuk berperan melindungi anak dari tindak pidana kejahatan.

4) Pencegahan

Upaya pencegahan terhadap anak sebagai korban pedofilia dapat dilakukan dengan cara memberikan penyuluhan dan sosialisasi kepada masyarakat tentang bahaya tindak pidana perbuatan salah seperti pedofilia terhadap anak-anak dan masa depan bangsa. Sehingga masyarakat lebih berhati-hati dan segera melaporkan kepada aparat penegak hukum jika terjadi tindak pidana perbuatan salah seperti pedofilia ini.

Selain itu upaya pencegahan juga dapat dilakukan dengan penyebarluasan dan sosialisasi ketentuan Peraturan Perundangundangan yang melindungi anak korban kejahatan seperti Undangundang Nomor 35 Tahun 2014 tentang Perlindungan Anak. Dengan adanya upaya-upaya ini diharapkan tindak pidana pedofilia dapat dicegah. Dalam upaya penanganan dan pemberantasan kasus pedofilia guna melindungi korbannya juga ditemui hambatan-hambatan, misalnya tidak adanya bukti kasus pedofilia, karena korban tidak mau melapor ke Kepolisian. Seringkali korban tidak mau melapor karena malu atau takut 
PRESUMPTION of LAW Fakultas Hukum Universitas Majalengka

Volume 3 Nomor 2 Oktober 2021

atas kejadian yang menimpanya.

Korban atau keluarga korban beranggapan kejadian yang menimpa korban adalah aib yang dapat membuat nama baik keluarga tercemar apabila diketahui oleh masyarakat luas. Selain tu korban adalah anak yang tidak berdaya, sehingga memilih bersikap pasrah, diam atau takut menceritakan apa yang dialaminya, menjauhkan diri dari pergaulan, merasa hina, berdosa dan lain sebagainya. Adanya sogokan dari pelaku kepada korban juga menyebabkan korban enggan melapor. ${ }^{24}$

\section{G. Kesimpulan}

1. Penegakan hukum tehadap pelaku tindak pidana pedofilia pada dasarnya memiliki tujuan pemidanaan yakni untuk memperbaiki pribadi dan penjahat itu sendiri, untuk membuat orang menjadi jera, untuk membuat penjahatpenjahat tertentu menjadi tidak mampu untuk melakukan kejahatan lain, Namun kenyataannya tidaklah demikian. didalam hukum positif Indonesia pemidanaan pelaku pedofilia sudah diatur di dalam Kitab Undang-Undang Hukum Pidana sebagai peraturan umum dan Peraturan Pemerintah Pengganti Undang-Undang Nomor 1 Tahun 2016 tentang perubahan kedua atas Undang-Undang Nomor 23 Tahun 2002 Tentang Perlindungan Anak sebagai peraturan khusus.

2. Faktor-faktor yang menyebabkan pedofilia adalah sebagai berikut :

a. Hubungan keluarga yang tidak harmonis, misalnya perceraian orangtua;

b. Riwayat sebagai korban kekerasan seksual saat masih berusia kanakkanak;

c. Gangguan kepribadian antisosial;

d. Depresi;

e. Faktor genetic;

f. Faktor lingkungan;

g. Ketidak seimbangan hormon seksual dan IQ yang rendah.

3. Perlindungan hukum terhadap anak yang menjadi korban pedofil adalah sebagai berikut :

a. Konseling;

b. Pelayanan / Bantuan Medis;

c. Bantuan Hukum;

d. Pencegahan.

\section{H.Saran}

1. Pemerintah dan DPR harus menambah jenis dan berat hukuman bagi pelaku tindak pidana pedofilia, serta memberikan sosialisasi terhadap seluruh masyrakat tentang dampak dari pedofilia terhadap anak agar mencegah terjadinya pedofilia kedepannya.

2. Orang tua harus menjaga anaknya dari tindak pidana pedofilia jangan sampai anak yang seharusnya dilindungi malah menjadi korban pedofilia

${ }^{24}$ Nur Humaira, Perlindungan Hukum Terhadap Anak Sebagai Koban Pedofilia, Jurnal Volume 2 Fakultas Hukum Universitas Syiah, Kuala, Tahun 2018 
dari orang terdekat, karena salah satu faktor penyebab pedofilia adalah pernah mengalami kekerasan seksual dimasa anak-anak.

3. Aparat penegakan hukum harus lebih memperhatikan perlindungan terhadap korban tindak pidana pedofilia, karena pedofilia dapat merusak fisik maupun mental terhadap anak itu sendiri. 


\section{DAFTAR PUSTAKA}

\section{A. Sumber Buku}

Alam dan Amir Ilyas, Kriminologi Suatu Pengantar, Pranadamedia Grup, Jakarta, 2018.

Bambang Waluyo, Viktimologi Perlindungan Korban dan Saksi, Sinar Grafika, Jakarta, 2012.

Ilham Bisri, Sistem Hukum Indonesia, Rajawali Pers, Jakarta, 2013.

Ismantoro Dwi Yuwono, Penerapan Hukum Dalam Kasus Kekerasan Seksual Terhadap Anak, Pustaka Yustisia, Yogyakarta, 2015.

Mahrus Ali, Dasar-Dasar Hukum Pidana, Sinar Grafika, Jakarta, 2015.

Maya Indah, Perlindungan Korban, Kencana Prenada Media Group, Jakarta, 2014.

Muhammad Mustofa, Metodologi Penelitian Kriminologi, Prenadamedia Grup, Jakarta, 2015.

Munir fuady, Teori dalam hukum, prenada media, Jakarta, 2013.

Romli Atmasasmita, Teori dan Kapita Selekta Kriminologi, PT Refika Aditama, Bandung, 2013.

Soerjono Soekanto, Faktor-Faktor Yang Mempengaruhi Penegakan Hukum, Rajawali Pers, Jakarta, 2016.

Tini Rusmini Gorda, Hukum Perlindungan Anak Korban Pedofilia, Setara Press, Malang, 2017.

Topo santoso dan eva achjani zulfa, Kriminologi, rajawali pers, Jakarta, 2011.

Zainuddin Ali, Metode Penelitian Hukum, Sinar Grafika, Jakarta, 2014.

\section{B. Sumber Peraturan Perundang-undangan}

Undang-Undang Dasar Negara Republik Indonesia Tahun 1945.

Kitab Undang-Undang Hukum Pidana.

Peraturan Presiden Republik Indonesia Nomor 61 Tahun 2016 Tentang Komisi Perlindungan Anak Indonesia. 
Peraturan Pemerintah Pengganti Perundang-Undangan Nomor 1 Tahun 2016 Tentang Perlindungan Anak.

\section{Sumber Lainnya}

Damang Averroes, Negara Hukum, https://www.NegaraHukum.Com, di akses pada tanggal 25 Mei 2021.

Desita Rahma Setia Wati, Tinjauan Tentang Perlindungan Hukum, https:/core.ac.uk. di akses pada tanggal 1 Juli 2021.

Dijilib, Landasan Teori, iain-palangkaraya.ac.id diakses pada tanggal 25 Mei 2021.

Helmi Romdhoni, Viktimologi Dan Kriminologi, http://www.inanews.co.id, di akses pada tanggal 9 Juni 2021.

Jimly Asshiddqie, Penegakan Hukum, www.jimly.com di akses pada tanggal 9 Juni 2021.

Lika aprilia samiadi, Prdofilia Penyebab, Resiko, Pengobatan, hellosehat.com, di akses pada tanggal 10 Juni 2021.

Novi Dwiria, Teori Penegakan Hukum, eprints.umm.ac.id di akses pada tanggal 28 Mei 2021.

Nurul Rafiqua, Pedofilia, https://www.sehatq.com/penyakit/pedofilia di akses pada tanggal 20 Juli 2021.

Portal, Pengertian Perlindungan Hukum, Universitasquality.ac.id. di akses pada tanggal 8 Juni 202 .

Prakoso dan Abintoro, Kriminologi Dan Hukum Pidana, Repository.unej.ac.id, di akses pada tanggal 15 Juni 2021.

Rena Yulia, Viktimologi Pelindungan Hukum Terhadap Korban Kejahatan, ejurnal.uajy.ac.id, di akses pada tanggal 15 Juni 2021.

Repository, Teori Kriminologi Penyebab Kejahatan, umy.ac.id, di akses pada tanggal 28 Mei 2021.

Teguh Prasetyo, Rule Of Law, Repository.uksw.edu.com di akses pada tanggal 15 Juni 2021.

Wantjik Saleh, Tinjauan Tentang Tindak Pidana, Repository.um. Palembang. ac.id diakses pada tanggal 1 Agustus 2021. 
Wati, Tinjauan Tentang Perlindungan Hukum Pedofilia, http://.Core.ac.uk di akses pada tanggal 25 Mei 2021.

Eko Setiawan, Kejahatan Seksual Pedofilia Dalam Perspektif Hukum Pidana dan Islam, jurnal hukum islam, volume 14 nomor 2, Fakultas Hukum Universitas Brawijaya, Malang, tahun 2014.

Nur Humaira, Perlindungan Hukum Terhadap Anak Sebagai Koban Pedofilia, Jurnal Volume 2 Fakultas Hukum Universitas Syiah, Kuala, Tahun 2018.

Sanyato, Penegakan Hukum Di Indonesia, Jurnal Dinamika Hukum, Volume 8 Nomor 3 Fakultas Hukum Universitas Jendral Soedirman, Purwokerto, Tahun 2008

Tri Novita, Korban Pedofilia, Jurnal Law Reform, Volume 12 Nomor 1 Fakultas Hukum, Universitas Diponegoro, tahun 2016.

Danny Rahadian, Implementasi Penegakan Hukum Pidana, Skripsi, Fakultas Hukum Universitas Majalengka 2018.

Panduan Skripsi, Fakultas Hukum universitas Majalengka, Cetakan Kesembilan 2021. 